\title{
Chemical Evaluation of Some Stevia (Stevia rebaudiana, Bertoni) Varieties of under Different Nitrogen Fertilization Levels
}

\author{
. A .A. Tantawy * .A.E. Attia **Nareyman. N. Kenawy. **. \\ *Agronomy Dept., Fac. of a Agric., Minia Universtity. **Agricultural Research Center, Giza, Egypt. \\ Correspondence author:nareyman33@Gmail.Com
}

\begin{abstract}
Two field experiments were carried out at agricultural research center, Giza, Egypt during 2015/2016 and 2016/2017 seasons to study the effect of nitrogen fertilizer levels (20,30 and $40 \mathrm{~kg} \mathrm{~N} / \mathrm{fed} / \mathrm{cut}$.) on some stevia varieties (china1, Egy1, spanti and shou2). The highest nitrogen rate of $40 \mathrm{~kg}$. N/fed /cut was significant in all studied yield andChemical characters and gave the highest values of stevioside\%. recorded $(6.09$ and $6.62 \%)$, ,rebaudioside A\% ( 7.23 and 8.04\%), Stevioside $\mathrm{kg} / \mathrm{fed}$ ( 238.9 and $286.1 \mathrm{~kg}$ ) and rebaudioside A $\mathrm{kg} / \mathrm{fed}$ $(287.2$ and $350.5 \mathrm{~kg})$ ), respectively as compared with the other two nitrogen treatments in both seasons.

Stevia Varieties were significantly different in all studied yield characters. china 1 Varieties gave the highest values of stevioside\% (6.83 and $7.34 \%$ ), rebaudioside A\% ( 8.44 and $9.26 \%$ ), rebaudioside A kg /fed(300.8 and $363.2 \mathrm{~kg}$ ), respectively of all studied yield and chemical characters except for dry leaves yield kg/fed where Egy1 varieties gave the highest values in the first and second seasons.

.Concerning the effect of the interaction between nitrogen fertilizer levels and stevia varieties on yield and chemical characters, nitrogen fertilizer level of $40 \mathrm{~kg} \mathrm{~N} / \mathrm{fed} / \mathrm{cut}$ applied to china1 varieties gave the highest values in all studied yield and chemical composition except for dry leaves yield $(\mathrm{kg} / \mathrm{fed})$ where Egy1 varieties and nitrogen fertilizer level of $40 \mathrm{~kg} \mathrm{~N} /$ fed/cut gave the highest values in the first and second seasons.
\end{abstract}

Key words: stevia, nitrogen fertilizer, varieties, stevioside, rebaudioside -A .

\section{Introduction}

Stevia is a new crop in Egypt. It was approved in 1995 for use as a food ingredient by Food Standard for Egypt. This plant is believed to be the most ideal substitute for sugar. Steviol Glycoside (SG) found in the leaves is responsible for the sweetness of stevia. As a new crop to for Egypt, commercial cultivation of stevia is yet to commence.

. Leaves of Stevia rebaudiana contains diterpene glycosides which taste sweet but with zero calories and 100-300 times sweeter than sugar (sucrose) (Megeji et al 2005 and Soejarto et al 1983).

This plant is believed to be the most ideal substitute for sugar and important to assist in medicinal value. Given its many health benefits, recent GRAS acceptance and existing evidence in support of stevia's safety for human consumption.namely stevioside, rebaudioside A, B, C, $\mathrm{D}$ and $\mathrm{E}$ (Geuns 2003). The plant is known to exhibit a wide range of biological activities like hypoglycemic, anti-oxidant, anticancer, antibacterial activities. Stevia contains a high percentage of phenols, flavonoids and antioxidant activity (Negar et al 2012). Stevia rebaudiana, Bertoni leaves are a natural source of diterpenic glycosides, and various bioactive compounds. characterize antioxidants (Danijela et al 2018 ). Stevia now is used as sweeteners to replace sugar in foods, beverages and medicines, stable at wide range of temperature and $\mathrm{pH}$ conditions during processing and offer no shelf life limitations,( Balwinder et al 2014). They are thermostable even at temperatures of up to 200 !C, making them suitable for use in cooked foods.(Roberto et al 2012).

\section{Materials and methods}

The present work was designed to study the respons of (yield and chemical properties of some stevia (Stevia rebaudiana, Bertani) varieties under different nitrogen fertilization levels. Two experiments were carried out at Agricultural Research Center, Giza, Egypt during 2015/2016 and 2016/2017 seasons.

Treatments: Two factors were studied as follow: Factor A: nitrogen fertilizer levels $(\mathbf{N}): \mathbf{N} 1=20 \mathrm{~kg}$ $\mathrm{N}$ fed/cut, $\mathrm{N} 2:=30 \mathrm{~kg} \mathrm{~N}$ fed/cut and N3=40 kg N fed/cut.

Factor B: Varieties (v): V1: china 1, V2 : Egy 1, V3 : spanti, V4 :shou 2.

Nitrogen fertilizer was applied in the form of urea $(46.5 \% \mathrm{~N})$ in two equal rates, the first rates was applied after 15 days of planting (or after cutting in the following cuts) and second rates was applied after 15 days from the first rates.

\section{Field Experimental Design:}

The experimental design used was a split plot design with three replicates, Fertilizer levels were arranged in the main plots and cultivars in the sub plots. The sub plot area was $10.8 \mathrm{~m} 2$ (6 ridges) 3.0 meters in the length and $60 \mathrm{~cm}$ in width The treatments (12) were the combinations of three nitrogen levels and four varieties 
Table (A ) Physical and Chemical analysis of experimental soils in 2015/2016and 2016/2017 seasons. Analysis

Seasons

Mechanical analysis

\begin{tabular}{|c|c|c|}
\hline Coasre sand $\%$ & 0.20 & 0.50 \\
\hline Fine sand \% & 12.16 & 14.2 \\
\hline Silt \% & 48.85 & 45.7 \\
\hline Clay $\%$ & 38.99 & 36.5 \\
\hline Textual class & Cilt clay loam & Cilt clay loam \\
\hline \multicolumn{3}{|l|}{ Chemical analysis } \\
\hline Organic matter $\%$ & 1.08 & 1.32 \\
\hline $\mathrm{CaCo} 3 \%$ & 1.10 & 2.0 \\
\hline $\mathrm{PH}(1: 2.5)^{* *}$ & 8.10 & 8.0 \\
\hline Soluble $\mathrm{Ca}++(\mathrm{meq} / 100 \mathrm{~g}$ soil $)$ & 11.2 & 16.2 \\
\hline Soluble Mg++ (meq /100 g soil ) & 10.7 & 14.7 \\
\hline Soluble $\mathrm{Na}+(\mathrm{meq} / 100 \mathrm{~g}$ soil $)$ & 8.3 & 11.7 \\
\hline Soluble K + (meq /100 g soil $)$ & 4.1 & 2.6 \\
\hline Soluble Co3 --(meq /100 g soil ) & -- & -- \\
\hline Soluble Hco 3--(meq /100 g soil ) & 3.5 & 5.6 \\
\hline Soluble $\mathrm{Cl}--(\mathrm{meq} / 100 \mathrm{~g}$ soil $)$ & 13.3 & 17.9 \\
\hline Soluble So4--(meq /100 g soil ) & 17.3 & 31.7 \\
\hline Available N(ppm) & $11.00 \%$ & $13.9 \%$ \\
\hline Available P( ppm) & $9.12 \%$ & $11 \%$ \\
\hline Available K(ppm ) & $35.86 \%$ & $34.1 \%$ \\
\hline
\end{tabular}

\section{Studied characters}

-Dry leaves yield $\mathrm{kg} / \mathrm{fed} /$ year

- Stevioside\%-

- Rebaudioside A\% -

- Stevioside yield (kg / fed / year ) -

- Rebaudioside Ayield ( $\mathrm{kg} / \mathrm{fed} /$ year )

\section{Statistical analysis:}

All collected data were statistically analyzed according to technique of analysis of variance for split- plot design by " GENSTAT Version $12^{\text {th }} 2009$ " computer software package (VSN International, Hemel Hempstead, UK) to determine The differences among treatment means were compared by L.S.D. test at $P \leq 0.05$ Payne, et al (2009). Combined analysis for the two seasons of experimentation was done according to the homogeneity of experimental error variance (Bartlett, 1937).

\section{Extraction and estimation of Stevia sweeteners in relation to total \\ Sweeteners \\ - Preparation of leaves for extraction}

Stevia leaves were dried in an electric oven (E.

Schulz \& Co. Inh. Franz. Skorezewsh KG) at $50^{\circ} \mathrm{C}$.

2. Stevia sweeteners

Stevia sweeteners were obtained from Stevia International Company for Agra industrial Projects (SKAP)

\section{Stevioside standard preparation}

Stevioside standard preparation was carried out according to Nishiyama et al. (1992) as follows: Dried Leaves (10 g leaves of Stevia rebaudiana,
Bertoni obtained from Sigma) were extracted by soaking leaves in 1.0 liter of water nearly boiling $\left(85^{\circ} \mathrm{C}\right)$ for 30 minutes. The resulting liquid fraction was separated by Buchner filtration and the residue was washed with an additional volume of hot water $(50 \mathrm{ml})$. The aqueous solution was concentrated by lyophyilization (Edwards Model EF03, England) to be $50 \mathrm{ml}$ and defatted by ethyl acetate, then extraction with isobutyl alcohol $(150 \mathrm{ml})$ was carried out.The aqueous phase was discarded and the organic solution was evaporated by rotary evaporator (Type 349, James Jobling and Co. Ltd., England) at $70^{\circ} \mathrm{C}$ until drying was obtained. The dried extract was dissolved in hot methanol $(100 \mathrm{ml})$ and kept over night to crystallize. The crystals were separated by filtration and re-dissolved again in boiling methanol (50 ml).This solution was clarified with active charcoal (B.D.H. Laboratory Chemicals Division. Poole, England) and left to recrystallize. The procedure was repeated three times until the formation of colorless crystals was observed. The pure solution of the stevioside prepared ( $\mathrm{pH}$ of 9) was subjected to HPLC.At the same time an authentic pure stevioside was obtained from $\mathrm{Nu}$ Naturals Inc. U.S.A.

\section{. Extraction of Stevia sweeteners from Stevia leaves with methanol (MeoH)}

Extraction of Stevia sweeteners from leaves were carried out by $0.5 \mathrm{gm}$ of dry stevia leaves was ground and dissolved in $0.5 \mathrm{ml}$ methanol and put in shaking and heating for 30 minutes at $70^{\circ} \mathrm{C}$ then kept in room temperature for cooling then abukhner funnel was used for filtiration using Afilter paper one time after 
that we used Activated charcoal for filtration another time finally we kept the filtrate frozen until analysis

Identification and quantitative analysis of Stevia sweeteners by HPLC in Stevia leaves extract

Stevia (Stevia rebaudianaBertoni) leaves extract was separated and identified on HPLC as follows: Stevioside and other sweet components standard as prepared above were filtered through a millipore membrane (13 $\mathrm{mm}$. diameter, $0.5 \mu \mathrm{m}$ pore size) were subjected for determination by chromatography with stevioside standard as internal standard. Different extracts of Stevia leaves were injected for chromatography Acetonitrile with HPLC grade (Fisons Co. England) was used in this study as mobile phase.HPLC separation was carried out on $210 \mathrm{~nm}$ (Agilent 1200PDA detector); Eclipse plus C18 column $(3.5 \mu \mathrm{m} 4.6 \times 250 \mathrm{~mm})$; linear gradient over 20 min (84:55\% $\mathrm{CH} 3 \mathrm{CN}$ in $\mathrm{H} 2 \mathrm{O} / 0.1 \%$ TFA); flow rate $2.0 \mathrm{~mL} / \mathrm{min}$. Injection volume: $70 \mu \mathrm{l}$ at ambient temperature $\left(25^{\circ} \mathrm{C}\right)$. All the conditions used were according to Makapugay et al., (1984). For each sample identification, quantification and the retention time were as described by Makapugay et al. (1984). Area under each peak was used to calculate the percent of each compound.

\section{Results and Discussion}

\section{Effect of nitrogen fertilizer levels}

Results in Table (1) indicate that dry leaves yield (kg/fed),.Stevioside yield ( $\mathrm{kg} / \mathrm{fed} /$ year ) and rebaudioside A yield ( $\mathrm{kg} / \mathrm{fed} /$ year ) were significantly affected by increasing nitrogen fertilizer levels in the first and second seasons. The highest nitrogen rate of $40 \mathrm{~kg} \mathrm{~N} / \mathrm{fed} /$ cut gave the highest values as compared with the other nitrogen treatments of all studied characters in both seasons. The highest values of dry leaves yield were (3640 and $4025 \mathrm{~kg}$ ), respectively, in 2015/2016 and 2016/2017seasons. These results are in agreement with Attia (2005), Lee et al . (1980), Chalapahti et al. (1999) and Ângelo et al ( 2017). Plants fertilized with $40 \mathrm{~N} \mathrm{~kg}$ / fed / cut had the highest values of stevioside\%. recorded (6.09and 6.62\%) respectively, in 2015/2016 and2016/2017seasons. Similar results were obtained by Attia (2005). Adding $40 \mathrm{~kg}$. N/fed/cut increased the values of rebaudioside A\% ( 7.23 and $8.04 \%$ ) in $2015 / 2016$ and 2016/2017season,respectively. Similar results were obtained by Geeta and Midmore (2017). Nitrogen fertilizer levels of $40 \mathrm{~kg} . \mathrm{N} / \mathrm{fed} / \mathrm{cut}$ gave the highest values of Stevioside yield $(\mathrm{kg} / \mathrm{fed} /$ year) (238.9 and $286.1 \mathrm{~kg}$ ) respectively, in the first and second seasons. Plants fertilized with $40 \mathrm{~N} \mathrm{~kg} /$ fed / cut had the highest values of rebaudioside A ( $\mathrm{kg}$ /fed/year) (287.2 and $350.5 \mathrm{~kg}$ ) ) respectively, in the first and second seasons. On the other hand, the lowest nitrogen rate of $20 \mathrm{~kg} \mathrm{~N} / \mathrm{fed}$ cut produced the lowest values of all studied characters in both seasons.

Discussion Nitrogen levels from 20to 30 and $40 \mathrm{~kg}$
.N/fed/ cut these increases may by attributed to the increase in content percentage Steviol Glycoside (SG), rebaudioside- A, in the leaves .These results are in agreement with those obtained by Rodrigues et al (2017), Attia (2005). Geeta and Midmore (2017).

\section{Effect of cultivars}

Data presented in Table (2) indicate clearly that stevia varieties were significantly different in dry leaves yield (kg/fed), Stevioside yield ( $\mathrm{kg} / \mathrm{fed} /$ year ) and rebaudioside A yield ( $\mathrm{kg} / \mathrm{fed} /$ year ) in the first and second seasons. Chinal varieties gave the highest values of all studied characters except dry leaves yield $\mathrm{kg} / \mathrm{fed}$ in the first and second seasons.

Egy1 Varieties gave the highest values dry leaves yield in the first and second seasons respectively. China1 varieties produced the highest values ofstevioside\%, respectively in 2015/2016 and 2016/2017seasons. Similar results were obtained by Asmaa Haraz (2016). The highest values of rebaudioside $\mathrm{A} \%$ were produced from china1 varieties in the first season. The current work is in agreement with Asmaa Haraz (2016) and Anami et al., (2016). China 1 varieties produced the highest values of stevioside $\mathrm{kg} / \mathrm{fed}$ yield/ year, in 2015/2016 and 2016/2017season. Similar results were obtained by Thiyagarajan and Venkatachalam (2015) and Anami et al., (2010). The highest values of rebaudioside A ( $\mathrm{kg} / \mathrm{fed} /$ year) was produced from china1 varieties respectively in the first seasons. The current work is in agreement with Asmaa Haraz (2016) . Mean while, spanti varieties gave the lowest values of all studied characters in both seasons.

\section{Discussion}

Such variation might reflect the efficiency of plant building metabolites or might be ascribed to genetical differences. These results are in agreement with those found by Asmaa Haraz(2016) and Thiyagarajan and Venkatachalam (2015)

\section{Effect of interaction between nitrogen fertilizer} levels and stevia cultivars

Data in Table ( 3 ) show that the interaction effect between nitrogen fertilizer levels and stevia varieties were significant for dry leaves yield $\mathrm{kg} / \mathrm{fed}$, Stevioside yield ( $\mathrm{kg} / \mathrm{fed} /$ year ) and rebaudioside A yield ( $\mathrm{kg} / \mathrm{fed} /$ year ). Nitrogen fertilizer levels of $40 \mathrm{~kg} \mathrm{~N} / \mathrm{fed} / \mathrm{cut}$ and China1 varieties gave the highest values of all studied characters except dry leaves yield in the first and second seasons. Nitrogen fertilizer level of $40 \mathrm{~kg} \mathrm{~N} / \mathrm{fed} / \mathrm{cut}$ and egy1 varieties gave highest values of dry leaves yield $\mathrm{kg} / \mathrm{fed}$ in 2015/2016 and 2016/2017season. Adding 40kg. N /fed / cut and China1 varieties recorded the highest values of stevioside \% in 2015/2016 and 2016/2017seasons. The highest values of rebaudioside $\mathrm{A} \%$ were obtained by treating China1 varieties with nitrogen rates of $40 \mathrm{~kg}$ $\mathrm{N}$ /fed / cut ,respectively in the first and second seasons. 
Table 1. Effect of nitrogen fertilizer levels on yield and chemical composition of stevia in 2015/2016 and 2016/2017 seasons.

\begin{tabular}{|c|c|c|c|c|c|c|c|c|c|c|}
\hline \multirow[t]{2}{*}{ characters } & \multicolumn{2}{|c|}{$\begin{array}{l}\text { Dry leaves yield kg /fed/ } \\
\text { year }\end{array}$} & \multicolumn{2}{|c|}{ Stevioside\% } & \multicolumn{2}{|c|}{ Rebaudioside A\% } & \multicolumn{2}{|c|}{ Stevioside $\mathrm{kg} / \mathrm{fed} /$ year } & \multicolumn{2}{|c|}{ Rebaudioside A kg /fed/ year } \\
\hline & $2015 / 2016$ & $2016 / 2017$ & $2015 / 2016$ & 2016/2017 & $2015 / 2016$ & 2016/2017 & $2015 / 2016$ & 2016/2017 & $2015 / 2016$ & 2016/2017 \\
\hline N1 & 2088 & 2651. & 2.98 & 3.28 & 3.69 & 3.93 & 69.6 & 99.4 & 87.6 & 119.3 \\
\hline $\mathbf{N 2}$ & 2743 & 3088. & 4.59 & 4.91 & 5.44 & 6.01 & 135.3 & 162.2 & 159.7 & 199.3 \\
\hline N3 & 3640 & 4025 & 6.09 & 6.62 & 7.23 & 8.04 & 238.9 & 286.1 & 287.2 & 350.5 \\
\hline Mean & 2824 & 3255 & 4.55 & 4.93 & 5.45 & 5.99 & 148.0 & 182.6 & 178.2 & 223.0 \\
\hline L s d 0.05 & 262.2 & 253.8 & - & - & - & - & 22.03 & 9.57 & 28.15 & 11.44 \\
\hline
\end{tabular}

N1: $20 \mathrm{~kg} \mathrm{~N}$ fed/cut. , N2: $30 \mathrm{~kg} \mathrm{~N}$ fed/cut , N3: $40 \mathrm{~kg} \mathrm{~N}$ fed/cut.

Table 2. Effect of cultivars on yield and chemical composition of stevia in 2015/2016 and 2016/2017 seasons.

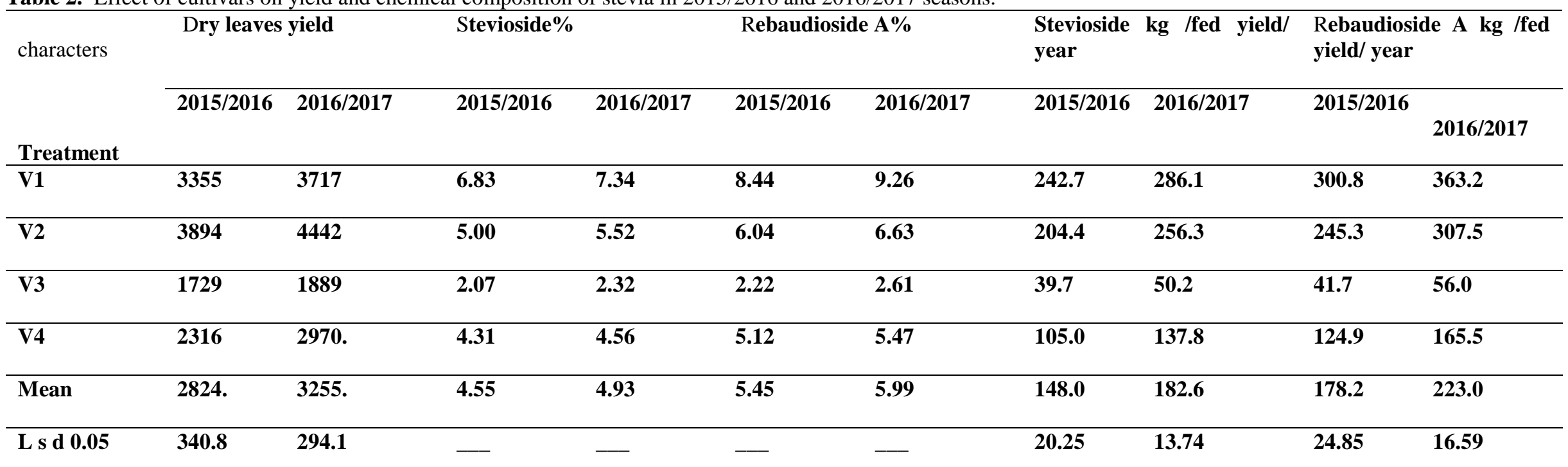

V1: China $1 \quad$ V2: Egy $1 \quad$ V3: Spanti, V4 : Shou 2 
Table 3. The interaction effect of between nitrogen fertilizer levels and stevia cultivars on chemical composition of stevia in $2015 / 2016$ and $2016 / 2017$ seasons

\begin{tabular}{|c|c|c|c|c|c|c|c|c|c|c|}
\hline \multirow{2}{*}{$\begin{array}{l}\text { Character } \\
\text { s } \\
\text { Treatment }\end{array}$} & \multicolumn{2}{|c|}{ Dry leaves yield } & \multicolumn{2}{|c|}{ Stevioside\% } & \multicolumn{2}{|c|}{ Rebaudioside A\% } & \multicolumn{2}{|c|}{$\begin{array}{l}\text { Stevioside kg /fed yield/ } \\
\text { year }\end{array}$} & \multicolumn{2}{|c|}{$\begin{array}{l}\text { Rebaudioside A kg /fed } \\
\text { yield/ year }\end{array}$} \\
\hline & $2015 / 2016$ & $2016 / 2017$ & $2015 / 2016$ & $2016 / 2017$ & $2015 / 2016$ & $2016 / 2017$ & $2015 / 2016$ & $2016 / 2017$ & $2015 / 2016$ & $2016 / 2017$ \\
\hline N1V1 & 2222 & 2701 & 4.89 & 5.22 & 5.87 & 6.26 & 108.7 & 141.0 & 130.3 & 169.2 \\
\hline N1V2 & 3009 & 3693 & 3.79 & 4.32 & 5.15 & 5.18 & 114.0 & 159.6 & 154.9 & 191.5 \\
\hline N1V3 & 1346 & 1351 & 0.34 & 0.33 & 0.33 & 0.41 & 4.6 & 4.5 & 4.4 & 5.4 \\
\hline N1V4 & 1773. & 2860 & 2.89 & 3.23 & 3.42 & 3.88 & 51.2 & 92.5 & 60.6 & 111.0 \\
\hline N2V1 & 3380 & 3735 & 7.06 & 7.61 & 8.93 & 9.63 & 238.7 & 284.1 & 301.8 & 359.6 \\
\hline N2V2 & 3848. & 4155 & 4.28 & 4.66 & 4.52 & 5.59 & 164.8 & 193.7 & 174.0 & 232.4 \\
\hline N2V3 & 1443 & 1764. & 2.76 & 2.95 & 3.26 & 3.54 & 98.0 & 52.0 & 47.1 & 62.4 \\
\hline N2V4 & 2302 & 2698 & 4.26 & 4.42 & 5.04 & 5.3 & 380.6 & 119.1 & 116.1 & 143.0 \\
\hline N3V1 & 4463 & 4716 & 8.53 & 9.18 & 10.54 & 11.89 & 380.6 & 433.1 & 470.2 & 560.8 \\
\hline N3V2 & 4824 & 5477 & 6.93 & 7.59 & 8.44 & 9.10 & 334.5 & 415.5 & 407.0 & 498.6 \\
\hline N3V3 & 2399 & 2552. & 3.11 & 3.69 & 3.07 & 3.92 & 74.7 & 94.2 & 73.7 & 100.1 \\
\hline N3V4 & 2875 . & 3353. & 5.77 & 6.02 & 6.88 & 7.23 & 165.8 & 201.8 & 197.9 & 242.5 \\
\hline mean & 2824. & 3255. & 4.55 & 4.93 & 5.45 & 5.99 & 148.0 & 182.6 & 178.2 & 223.0 \\
\hline L s d 0.05 & 541.8 & 475.1 & - & - & - & - & 34.24 & 21.60 & 42.45 & 26.07 \\
\hline
\end{tabular}

N1: $20 \mathrm{~kg} \mathrm{~N}$ fed/cut., $\quad$ N2: $30 \mathrm{~kg} \mathrm{~N}$ fed/cut, $\quad$ N3: $40 \mathrm{~kg} \mathrm{~N}$ fed/cut.

$\begin{array}{lll}\text { V1: China } 1 & \text { V2: Egy } 1 \quad \text { V3: Spanti, } & \text { V4 :Shou } 2\end{array}$ 
Nitrogen fertilizer level of $40 \mathrm{~kg} \mathrm{~N} / \mathrm{fed} / \mathrm{cut}$ and china 1 varieties gave highest values of stevioside $(\mathrm{kg}$ /fed / year) in 2015/2016 and 2016/2017seasons, respectively. Adding 40kg. N /fed / cut to China1 varieties recorded the highest values of rebaudioside A ( $\mathrm{kg} / \mathrm{fed} /$ year $)$ respectively in the first and second seasons.

\section{References}

Attia.E. A (2005) Effect of some agronomic treatments on stevia (stevia rebaudiana,bertoni) yield and quality in egypt. Ph D thesis.Fac of AgricAin shams Univ. Egypt.

Asmaa Haraz S, M (2016) Genetic improvement through selection of Stevia rebaudiana under Egyptian conditions. M.Sc.thesis, Fac of Agric Saba Basha . Alexandria Univ. Egypt.

Anami, E. T, J. P. Poletine, M. C. GonçalvesVidigal, P. S. V. Filho, G. F. Lacanallo, M. V. Kvitschal and A. Gonela (2010). Characterization and genetic divergence in Stevia rebaudiana(Bert.)Bertoni clones based in agronomical and morphological characteristics. Journal of Food, Agriculture \& Environment.8 $(3 \& 4): 463-469$

Bartlett, M. S. (1937). Properties of sufficiency and statistical tests. Proceedings of the London. Series A-Math. Phys. Royal Society of Sci., 160(901): 268282.

Chalapathi, M. V., S.Thimmegowda, G. G. E.Rao, N. Devakumar and J.Chandraprakash (1999).Influence of fertilizer level on growth, yield and nutrient uptake of ratooncrop of stevia (Stevia rebaudiana). Journal of Medical and Aromatic Plant Sci.21 : 947-949.

Kovacevi. D. B, F. J. Barba, D. Granato, C. M.Galanakis, Z. Herceg, V. D. Uzelac and P.Putnik (2018) Pressurized hot water extraction (PHWE) for the green recovery of bioactive compounds and steviol glycosides from Stevia rebaudiana Bertoni leaves. Food Chemistry. Vol 254, 15 July, 150-157

Putnik Geuns, J. M. C. (2003).Stevioside.Phytochemistry, 64(5): 913921.

Geeta. G.K, Dd. J. Midmore and R.Gautam(2017) Effect of nutrient omission and $\mathrm{pH}$ on the biomass and concentration and content of steviol glycosides in stevia (Stevia rebaudiana (Bertoni) Bertoni) under hydroponic conditions. Journal of Applied Research on Medicinal and Aromatic Plants. Vol 7, December , 136-142

Lee, J. I, K. H. Kang, H. W. Park,Y. S Ham and C. H Park( 1980) Studies on the new sweetening source plant, Stevia rebaudiana in Korea. II.
Effects of fertilizer rates and planting density on dry leaf yields and various agronomic characteristics of Stevia rebaudiana. Research Reports of the Office of Rural Development, Crop, Suwon Vol.22: 138-144

Makapugay, H. C., N.P.D. Nanayakkara and A.D. Kinghorn (1984). Improve high-performance liquid chromatographic separation of the Stevia rebaudianasweetditerpene glycosides using linear gradient elution. Journal of Chromatography A. $283:$ 390-395

Negar T., Y. Hamidoghli, B. Rabiei and S. Hamidoghli (2012 )Effects of plant density and transplanting date on herbage, stevioside, phenol and flavonoid yield of Stevia rebaudiana Bertoni. Intl J Agra Crop Sci. Vol., 4 (6), 298-302

Nishyama, P., M. Alvarez and L. G. E. Vieira (1992).Quantitative analysis of stevioside in the leaves of Stevia rebaudianabynea $\mathrm{r}$ infrared reflectance spectroscopy. Journal of Science Food and Agriculture. 59(3) 277-281.

Megeji . N. W., J. K. Kumar, Virendra Singh, V. K. Kaul and P. S. Ahuja 2005 Introducing Stevia rebaudiana, a natural zero-calorie sweetener. Current Sci Vol.( 5) : 801-804

Payne, R. W., D. A. Murray, S. A. Harding, D. B. Baird and D. M. Soutar (2009). Gen Stat for Windows $\left(12^{\text {th }}\right.$ Edition $)$ Introduction. VSN International, Hempstead, UK.

Rodrigues. A .M , SandraAfonso, Isabel Q. Ferreira and Margarida. A (2017) Response of stevia to nitrogen fertilization and harvesting reime in northeastern Portugal .j0urnal Archives of Agronomy and Soil Science. Volume 63 : 626637

Roberto .L.M, A. V.Gálvez, Liliana Z..B and Kong A .H ( 2012) Stevia rebaudianaBertoni, source of a high-potency natural sweetener: A comprehensive review on the biochemical, nutritional and functional aspects . Food Chemistry $132: 1121-113$

Singh. B, J. Singh, A. Kaur (2014)Agro-production, Processing and Utilization of Stevia rebaudianaas Natural Sweetener . Journal of Agri Engineering and Food Technology; Vol 1, (1) 28-31

Soejarto .D.D, Compadre .C.M, Medon PJ, Kameth .S.K, Kinghorn

.A.D( 1983). Potential sweetening agents of plant origin. II. Field search for

sweet tasting Stevia species. Econ Bot; 37: 71-9

Thiyagarajan, $M$ and $P$. Venkatachalam (2015).Assessment of genetic and biochemical diversity ofSteviarebaudianaBertoni by DNA fingerprinting and HPLC analysis.Journal of Annals of Phytomedicine. 4(1): 79-85. 


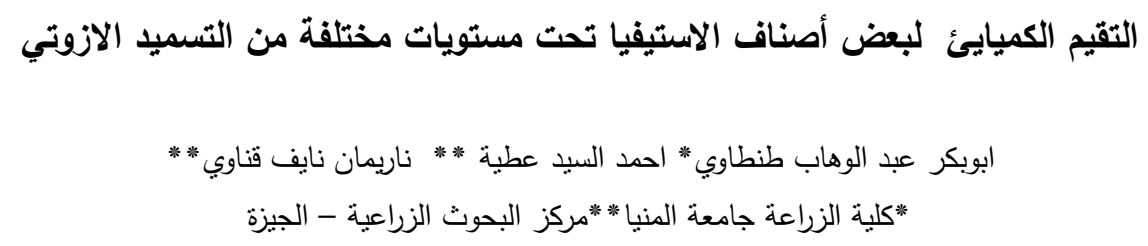

اجريت الدراسة في محطة بحوث الجيزة مركز البحوث الزراعية موسمي 2015- 2016 و 2016-2017 لدراسة تاثير النسميد النتروجينى (20)

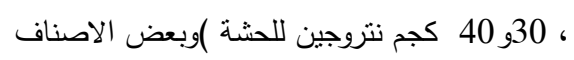
(shou 2 و و spantil،china 1،egy 1)

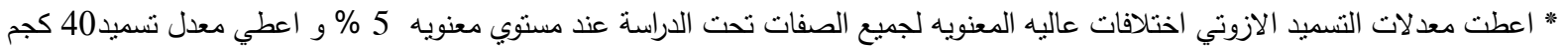

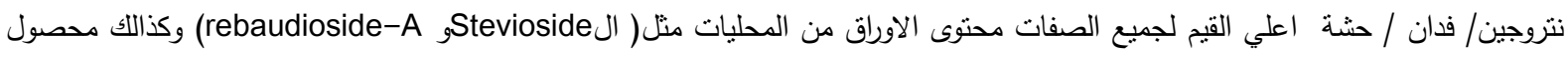
الفدان من المحليات منل( ال rebaudioside-AgStevioside) في السنه مقارنة بالمعاملات الاخري في الموسمين وكذللك المحصول الجاف • الأوراق

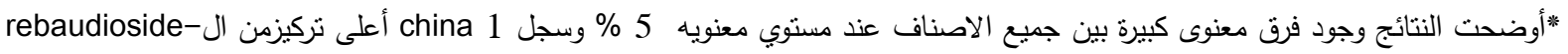

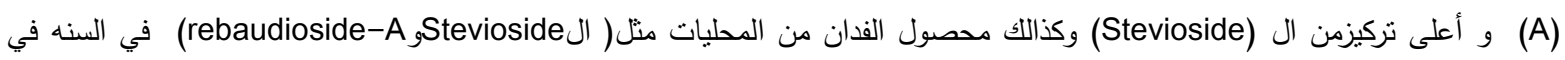
الموسمين مقارنه بالاصناف الاخري

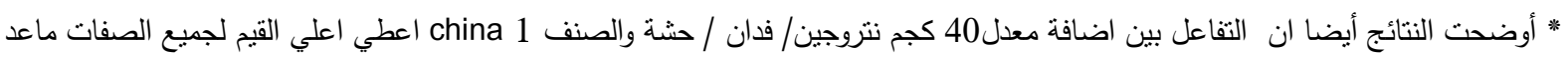
كميه محصول الفدان من الاوراق الجافه هيث سجل التفاعل بين اضافة معدل 40 كجم نتروجين للحشة والصنف egy1 اعلي كمية محصول

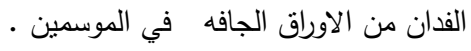

